\title{
Correction to: Provision and Need for Medicine Information in Asia and Africa: A Scoping Review of the Literature
}

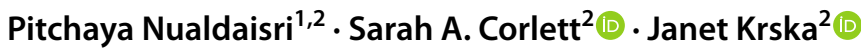

Published online: 13 July 2021

C Springer Nature Switzerland AG 2021

\section{Correction to: Drug Safety (2021) 44:421-437 https://doi.org/10.1007/s40264-020-01038-8}

The article Provision and Need for Medicine Information in Asia and Africa: A Scoping Review of the Literature, written by Pitchaya Nualdaisri, Sarah A. Corlett, Janet Krska, was originally published online on 5th March, 2021 with Open Access under a Creative Commons Attribution-NonCommercial 4.0 International License, which permits any non-commercial use, sharing, adaptation, distribution and reproduction in any medium or format, as long as you give appropriate credit to the original author(s) and the source, provide a link to the Creative Commons licence, and indicate if changes were made. The images or other third party material in this article are included in the article's Creative Commons licence, unless indicated otherwise in a credit line to the material. If material is not included in the article's Creative Commons licence and your intended use is not permitted by statutory regulation or exceeds the permitted use, you will need to obtain permission directly from the copyright holder. To view a copy of this licence, visit http:// creativecommons.org/licenses/by-nc/4.0/

The original article can be found online at https://doi.org/10.1007/ s40264-020-01038-8.

Janet Krska

j.krska@kent.ac.uk

1 Faculty of Pharmaceutical Sciences, Prince of Songkla University, Hatyai, Thailand

2 Medway School of Pharmacy, Universities of Kent and Greenwich, Chatham Maritime, Kent, UK
After publication in volume 44, issue 4, page 421-437 the author(s) decided to cancel the Open Access. Therefore, the copyright of the article has been changed on 16th June, 2021 to () Springer Nature Switzerland AG 2021 with all rights reserved.

The original article has been corrected. 